\title{
A History of a West Coast Firm Being Written at Stanford University
}

Pope \& Talbot, Inc., pioneer San Francisco lumber and shipping firm, has made a $\$ 17,500$ grant to the Stanford Graduate School of Business for the writing of the hundred-year history of the firm.

The research and writing will be done by Edwin T. Coman, director of the Graduate School of Business Library and assistant professor of business history. Miss Helen Gibbs, as research associate, will assist in the research and writing.

The history will trace the development of the company from East Machias, Maine, throughout California and the Pacific Northwest. It will also touch on the many long-standing trade outlets developed by the company in China, the Hawaiian Islands, Central and South America, and South Africa. The centennial of this concern coincides with that of the gold rush in California.

A notable feature for a Pacific Coast business is that the control and management rest in the hands of the third generation of the family, George A. Pope, Jr., president and Fred C. Talbot, first vice-president. Charles $\mathrm{L}$. Wheeler is executive vice-president of the firm.

Professor Coman expects to complete the research and writing within eighteen months. The results are to be published by the Stanford University Press as a book which will be one of the Stanford Graduate School of Business research series.

Carl E. McDowell, assistant to the executive vice-president of Pope \& Talbot, Inc., and lecturer in the Stanford Graduate School of Business, will serve with a committee of Business School faculty members as an advisory board for the project.

The history of business, a new field of research and teaching on the West Coast, was initiated in 1946 at Stanford by Professor Coman after his return to the Stanford faculty from service with the Army Air Forces. 